\title{
Role of Influencer Marketing in Promoting Financial Products in the Banking Sector of Pakistan
}

\author{
Rizwan Tariq ${ }^{1 *}$ Uma Mohan ${ }^{2}$ Nosheen Maqbool ${ }^{3}$ Umair Zahid $^{4}$ Mudassar Hussain ${ }^{5}$ Junaid Khan $^{6}$ \\ 1. University of the West of Scotland, London Campus, London SE1 6NP \\ 2. London School of Commerce, Chaucer House, White Hart Yard, London SE1 1NX \\ 3. University of the West of Scotland, London Campus, London SE1 6NP \\ 4. University of the West of Scotland, London Campus, London SE1 6NP \\ 5. University of the West of Scotland, London Campus, London SE1 6NP \\ 6. University of the West of Scotland, London Campus, London SE1 6NP \\ * E-mail of the corresponding author: rizwantariq106@gmail.com
}

\begin{abstract}
Purpose: The aim of this paper is to analyse the role of influencer marketing in promoting financial products in the banking sector of Pakistan and also to identify the factors through which banks are successfully implementing influencer marketing.

Research Design: In this study, the researcher adopted quantitative research design, and all the data were collected through survey questionnaires using five-point Liker scale, and a sample of 300 consumers were selected in Pakistan. The collected data analysed by the researcher through Frequency analysis and Correlation analysis. In addition to this, as the researcher employed the instrument of questionnaire, thereby, to check the reliability of the instrument, the reliably testing was done, and the instrument was found to be reliable.

Findings: It was found in the study that there was strong relationship between the influencer marketing and promotion of financial products. The study has found that customer reach, customer preference and engagement, shareable content and promotional tools are the factors through which banks are practising influencer marketing. Besides, it was further analysed that on the promotion of financial products in Pakistani banking sector.

Limitations: The main limitation of the study is that this study specifically focused on the banking sector of Pakistan, which means the findings of the study is limited to the banking sector of Pakistan only. Besides, there had been limited knowledge possessed by respondents despite the awareness of the topic as they were all consumers, and not bank managers or experts, so future studies can be conducted among bank managers or field experts.
\end{abstract}

Keywords: Digital Marketing, Influencer Marketing, Customer Engagement, Financial Products, Banking, Pakistan

DOI: $10.7176 / \mathrm{JMCR} / 68-06$

Publication date:June $30^{\text {th }} 2020$

\section{Introduction}

The art of science of working closely with the influential people to create awareness of the goods and services that are offered by a company is defined as influencer marketing. It has been observed that in the recent times, to ensure the optimal level of engagement with the customers, there is exceptional significance has been gained by the concept of influencer marketing (Vivek et al., 2012). Moreover, it has been inferred in a study conducted Weiss (2013) that influencer marketing is preferred by $75 \%$ of the professionals worldwide in order connect with potential and existing customers. A shift from traditional marketing to social media marketing has been seen in most of the modern businesses (Chikandiwa et al., 2013). The influencing personalities who have massive fan base on social media platforms, such as Facebook, Twitter, Instagram and YouTube are greatly been considered by companies. Both the opinion leaders and celebrity endorsement play a crucial role in influencer marketing, and the purchasing decision is influenced by them (El Khoury and Farah, 2018).

Therefore, the sales of banks can be boosted by using celebrity endorsers in the social media platform, and other techniques of influencer marketing. When it comes to the banking sector of Pakistan, its scope is continuously expanding (Kouser and Saba, 2011). In the year of 2009, the increase in the banking sector of Pakistan took place, while in the year of 2003, the highest spread of the banking industry was observed. It has been observed that in the same year, great profit was provided to the shareholders due to which the overall money investment was increased (Aftab, 2012). However, in the recent times, the risk of decreasing the revenue generation is more 
prevalent in the banks operating in Pakistan (Bokhari, 2017).

Furthermore, it has been observed that as compare to the international counterparts, the banking sector of Pakistan is quite behind in influencer marketing techniques. Therefore, considering these issues, this study is intended to assess the significance of the influencer marketing in promoting financial products in Pakistani banking sector and will also identify the determinants of influencer marketing helping Pakistani banks in promoting financial products. This study explores Influencer marketing in the perspective of Pakistani banking industry. Moreover, the banks in Pakistan can compete with the international standard banks globally and can get benefit by utilising influencer marketing In addition to this, the fact that customer satisfaction along with engagement can be attained through the help of influencer marketing has also been identified in the paper (Rizwan, et al., 2016).

It has been identified that in the context of banking sector of Pakistan, there is not adequate amount of studies available, while in the studies in which Pakistani banking sector discussed were more about the comparison between Islamic and traditional banking or performance of banks, and therefore, this constitutes a gap in the literature (Mir et al., 2019). Moreover, when it comes to discussing influencer marketing in banking sector of Pakistan, there is scarce in studies (Bokunewicz and Shulman, 2017). Therefore, this study is aimed towards providing an efficient way to the Pakistani banking sector, which will help to enhance the business operations and its favourability among the customers and by promoting the products and services, the attention of consumers can be enticed towards the offerings.

\section{Literature Review}

\subsection{Concept of Influencer Marketing}

Gretzel (2018); Jin, et al. (2019) has defined influencer marketing as a rapid growing industry which emphasises on the promotion of the products and services through the content which is spread by the social media users which are considered to be influential. Furthermore, it is illustrated as a technology that relies on the combination of reach, resonance and relevance for enhancing the word of mouth either through unpaid from the micro-influencers. With respect to the study of Kim and Kim (2019), the term influencer marketing is a newly concept which is new for many of the marketers and majority of them are not utilising in its marketing strategy. In addition, Cha et al. (2010) has indicated that the influencer marketing is considered to be an effective strategy that influences the consumers to change their behaviour and attitude with respect to the products and services. Thus, influencer marketing has opened new doors for creating awareness among the financial product in Pakistan.

\subsection{Kinds of Influencer Marketing}

For a smooth adaptation of influencer marketing, the organisations are obliged to employ the most suitable tactic as per the nature of their business. This is the reason that several kinds of influencers have evolved around the world in recent years. Accordingly, different studies are conducted by several analysts to indicate the tendency of promotion among the marketing tactics that are practiced by the recent firms. In association, some of the most common kinds of influencer marketing tactics are referral influencer, online influencers, topical influencers, expert influencer, positional influencer, micro, macro and mega influencers (Ruiz-Gomez, 2019; Florian, 2015). A brief review regarding each of the influencer is descripted below; at first, the referent influencer is defined as a user in the consumer's social circle that influences the customer's buying behavior by sharing their own reviews and experiences through the social media platforms (Bodimeade et al., 2014).

Moreover, referent influencers are personally aware of the consumers and so their opinion matters explicitly for the consumers (Sundaram, 2017). Second is the online influencers that are determined as the most active individuals on social media that stimulates the buying decision of the consumers (Florian, 2015). Unlike referent influencers, these people may or may not belong to the social circle of the consumer and only influences the buying behaviour through their own preference and audience value (Bhattacharya, 2018). Third is the topical influencer also defined as industry influencers with millions of followers over social media platforms (Shannahan et al., 2016). The only aspect that distinguish them from referent and online influencers is their peculiar industry credibility. After the discussion of technology backed influencers, some marketers also employ traditional influencers such as expert and positional influencers. According to Abdallah (2015), expert influencers are the personnel with high experience regarding a specific product or service. Therefore, at the time of high consideration purchases, the consumers prefer to obtain expert influencer's suggestions. Simultaneously, a position of the influencer closer to the consumer's preference and purchase decision give rise to position influencers. Altogether, these kinds of influencers stimulate the buying decision and purchase behaviour of the consumers.

\subsection{Pros and Cons of Influencer Marketing on Banking Sector}

Several banks that are operating in Pakistan are exploring for marketing tools that are influential with respect to the awareness of the customers, increasing the customer engagement and also enhancing the loyalty (Haleem, 
2015). Moreover, the study conducted by Lou and Yuan (2019) that the influential marketing has significantly grown over the years. The increasing of the influencer marketing is due to playing a major role in appealing brands while also being considered more affordable in comparison signing one or more recognised celebrities. Moreover, the study conducted by Berne-Manero and Marzo-Navarro (2020) has indicated that influencer marketing strengths the relationship goals in marketing where several platforms such as Instagram is utilised for creating awareness of the products and services particularly in the banks. On the contrary, the major issues that is faced with respect to influencer marketing or social media marketing is the trust issues. The study conducted by Kumar and Pradhan (2018) has indicated that the customer trust in the social media advertising is fairly low due to increasing fake media exposures. Thus, the trust issue is considered to be the major limitation for utilising influencer marketing. Hence, it can be illustrated that the banking sectors are commonly with trust issues with respect to influencer marketing.

\subsection{Factors of Customer Engagement}

According to Morgan and Engwall (2018) customer engagement is defined as emotional association between a consumer and the brand. In this regard, there are several factors to which the customer's engagement is stimulus. Practically, customer awareness, consideration, experience, loyalty and familiarity are highlighted by certain analysts as the most critical determinants of customer engagement (Biaudet, 2017; Bokunewicz \& Shulman, 2017). These factors are considered important as they steer the customers' preference regarding a brand that in turn earns the brand equity to contemporary businesses. Briefly, customer awareness is defined as tendency of a company to establish a source of communication channel among the customer and the brand to cater their needs accordingly (Janefer \& Siddiq, 2017).

Similarly, the customer consideration is denoted as capacity of a firm to cater the needs and wants to their customers. Additionally, customer experience and loyalty are the positive and consistent level of satisfaction that the consumer has experienced while consuming the product or service offered by the brand (Angelini et al., 2017). In the context of banking sector, all these determinants act significantly as the consumers change their preference based on their engagement level with the financial service providers.

\subsection{Causality between Influencer Marketing and Customer Engagement}

The most important role of the influencer marketing is to enhance the perception and opinion of the customers in terms of the products and services. Thus, the major goal of the influencer marketing is to enhance the profitability, productivity and acquisition of products and services (Choudhury, 2014). The use of social media platforms has enabled in customer engagement through the influencer marketing. The influencer marketing has a direct effect on the overall decision of the customers which leads towards their satisfaction and comfort. In addition, the positive effect which is identified on the influencer marketing is that it has an intensive customer engagement (Van Staden and Van Niekerk, 2018). There are various theories used in this study associated with influencer marketing, but the most appropriate method related to this research are used. Such as the information manipulation theory deliberates that unreliable communication function illusorily because they secretly infringe the moralities that govern conversationally (BenYoussef \& Breton, 2016). The theory of conversion behaviour which discusses the certain motives which transform the behaviour of consumer comprising the effect of majority and minority influence (Dongmei \& Xinxin, 2018).

The Social Impact Theory is referent the behaviour and attitude of others across three procedures which are internalisation, identification and compliance. All theories have a different concept associated with influencer marketing and emphasis the theoretical existence of this research. The concept of these theories suggests that the prediction of behaviour and perception of consumers about the specific products of banking sector of Pakistan. Through the integration of aforementioned concepts into the operations of marketing the banking sector of Pakistan can increase the engagement of customers by through promotion of products. 


\subsection{Conceptual Framework}

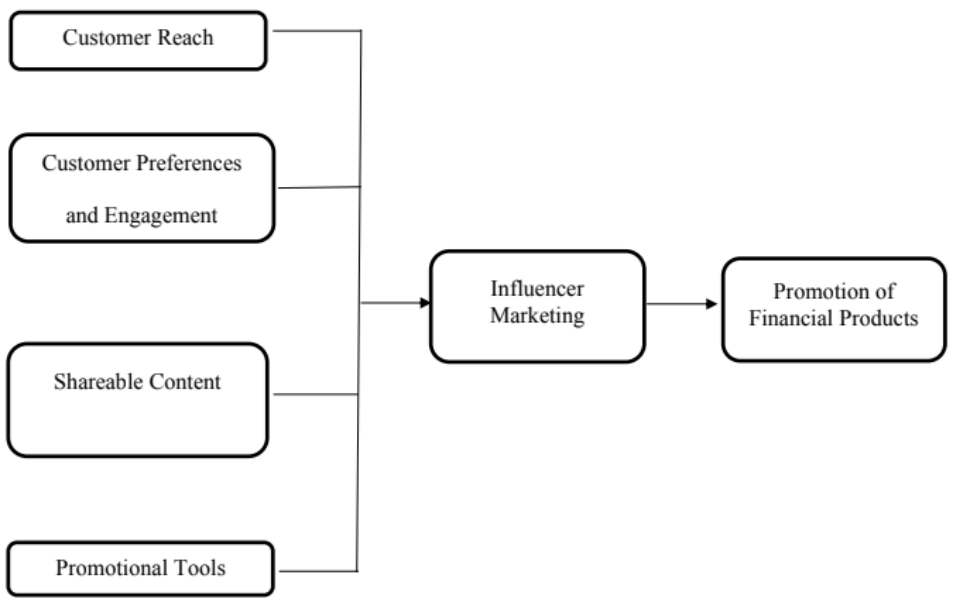

Figure 1: Conceptual Framework

The independent variables of the research related to identification of role of influencer marketing in promoting financial products in the banking sector of Pakistan are customer research, shareable content, promotional tools and customer preference and engagement. Likewise, the dependent variable of the research is promotion of financial products. The brief explanation of all independent variables and dependent variable is given below:

Customer Reach: Potential number of customers that can be reached by business is known as customer reach (Brown \& Hayes 2008).

Customer Preference and Engagement: The likes, dislikes and motivations and inclinations that drive customer purchasing decisions is known as customer preferences, while customer engagement is known as the emotional connection between a customer and a brand (Brown \& Hayes, 2008).

Shareable Content: A content that shared with an intention to gain traffic on the particular website is known as shareable content (Biaudet, 2017).

Promotional Tools: The tactics or activities that are used to persuade consumers to buy the products and services are considered as promotional tools. Traditional media, digital marketing and direction are the examples of financial tools (Abdallah, 2015)

Promotion of Financial Products: It is considered the instrument which help the individuals to invest, save, and get a mortgage or insurance (Abdallah, 2015)

\subsection{Research Method}

\subsection{Research Design}

The quantitative research design in which the quantifiable evidences are collected has been adopted in the present research. The reason to use this design by the researcher is that it has enabled the researcher to use large sample size to conduct the study. Moreover, the present research is aimed to focus on the banking sector of Pakistan, which a very large segment as the Pakistani banking sector has been expanded in recent years, therefore, useful insights cannot be provided by employer lower sample size (Leavy, 2017). Besides, another reason to use this design is that to conduct this research, there had been limited time available for the researcher, and therefore, in real time scenarios, the information can be collected by employing this method. In addition to this, statistical analysis can be done immediately.

\subsection{Collection of Data, Sample and Techniques}

In the present study, the researcher collected the quantitative data through primary sources. The reason to collect data from primary sources was that the information that was collected from primary source was more credible, accurate and authentic. Besides, in this case, the researcher was the owner of the information (Johnston, 2017). The sample size that was taken is 300 , and all the participant were consumers. Thus, the researcher used questionnaires and dispersed them in the consumers of Pakistani banking sector. The sampling technique that was used by the researcher to obtain the sample size was the non-probability convenience sampling. There were various 
reasons that propelled the researcher to use this technique (Etikan, Alkassim \& Abubakar, 2016). First, the respondents belong to different cities of Pakistan, and this technique enabled the researcher to collect data as per his convince. Second, the researcher had low budget and limited time to conduct this study, and therefore, this technique was cost effective and time saving.

\subsection{Data Analysis and Reliability Testing}

In the present study quantitative data were accumulated through questionnaire, and therefore, to analyse the quantitative data, the researcher employed the frequency analysis and correlation. Therefore, each response of the respondents obtained through questionnaire was analysed through frequency analysis. While, to evaluate the strength of relationship between independent and dependent variables, the correlation analysis was conducted by the researcher (Gogtay \& Thatte, 2017). In addition to this, as the researcher employed the instrument of questionnaire, thereby, to check the reliability of the instrument, the reliably testing is done by the researcher (Smith et al., 2017). However, the instrument was found to be reliable in the test as the results are significant and the value is greater than 0.6 . All the test performed by the researcher by employing the statistical tools of SPSS.

\section{Reliability Statistics}

\begin{tabular}{|r|r|}
\hline $\begin{array}{c}\text { Cronbach's } \\
\text { Alpha }\end{array}$ & N of Items \\
\hline .998 & 41 \\
\hline
\end{tabular}

\subsection{Analysis and Results}

\subsection{Descriptive Statistics}

With the help of median, the computation of the central tendencies of ordinal variables can be done, while with the help of arithmetic means, the computation of central tendencies of the interval or ratio variables can be done (Sekaran \& Bougie, 2016). In measuring variables of this study, the ordinal 'Likert-scales' were used. When it comes to the main variable of the study, promotion of the financial products, promotional tools, shareable content, customer preferences, customer reach and engagement are included in it. The table presented below has depicted the results of descriptive statistics obtained through SPSS.

Table 1: Descriptive Statistics

\begin{tabular}{|c|c|c|c|c|c|c|}
\hline \multicolumn{7}{|c|}{ Statistics } \\
\hline & & $\begin{array}{c}\text { Customer } \\
\text { Reach }\end{array}$ & $\begin{array}{c}\text { Customer } \\
\text { Preferences }\end{array}$ & $\begin{array}{c}\text { Shareable } \\
\text { Content }\end{array}$ & $\begin{array}{c}\text { Promotional } \\
\text { Tools }\end{array}$ & $\begin{array}{c}\text { Promotion of } \\
\text { Financial } \\
\text { Products } \\
\end{array}$ \\
\hline \multirow[t]{2}{*}{$\mathrm{N}$} & Valid & 300 & 300 & 300 & 300 & 300 \\
\hline & Missing & 0 & 0 & 0 & 0 & 0 \\
\hline & & 1.00000000 & 1.00000000 & 1.00000000 & 2.75000 & 1.22222200 \\
\hline
\end{tabular}

Based on the above table, it can be understood that as compare to the median of shareable content (1), customer preferences and engagement (1) and customer reach (1), the median of promotional tools is higher, which is 2.75 . On the other side, there is (1.2222) median revealed promotion of financial products. Therefore, in the Pakistani banking sector, there is higher perception of promotional tools. Besides, it has also been indicated by the above findings that the promotional tools, such as digital marketing, traditional marketing, public relation to promote financial products, loyalty discounts, electronic words of mouth, trust and consistency are more focused to be used banks in Pakistan. 


\subsubsection{Frequency Analysis}

Bank Names

Table 2: Respondents' Name of the Banks

\begin{tabular}{|c|c|c|c|c|c|}
\hline & & Frequency & Percent & Valid Percent & $\begin{array}{c}\text { Cumulative } \\
\text { Percent }\end{array}$ \\
\hline \multirow[t]{7}{*}{ Valid } & Islamic Bank & 34 & 11.3 & 11.3 & 11.3 \\
\hline & Standard Chartered & 72 & 24.0 & 24.0 & 35.3 \\
\hline & United Bank Limited & 103 & 34.3 & 34.3 & 69.7 \\
\hline & Habib Bank Limited & 60 & 20.0 & 20.0 & 89.7 \\
\hline & Bank Alfalah & 7 & 2.3 & 2.3 & 92.0 \\
\hline & Other & 24 & 8.0 & 8.0 & 100.0 \\
\hline & Total & 300 & 100.0 & 100.0 & \\
\hline
\end{tabular}

Based on the above table, it can be stated that in UBL, 34\% of the respondents have their accounts, while in Standard Chartered, this 24\%, in Habib Bank, 20\%, in Islamic Bank, 11\%. Besides, Bank Alfalah and other banks, $23 \%$ and $8 \%$ of the respondents have their accounts respectively.

\section{Customer with Bank}

Table 3: Customers Associated with Bank How long you have been a customer with the bank?

\begin{tabular}{|ll|r|r|r|r|}
\hline & Frequency & Percent & Valid Percent & $\begin{array}{c}\text { Cumulative } \\
\text { Percent }\end{array}$ \\
\hline Valid & 1-2 years & 79 & 26.3 & 26.3 & 26.3 \\
& 2-3 years & 46 & 15.3 & 15.3 & 41.7 \\
& 36 & 12.0 & 12.0 & 53.7 \\
& 4-5 years & 11 & 3.7 & 3.7 & 57.3 \\
& 5-6 years & 29 & 9.7 & 9.7 & 67.0 \\
6-7 years & 34 & 11.3 & 11.3 & 78.3 \\
& 7-8 years & 34 & 11.3 & 11.3 & 89.7 \\
& More than 8 years & 31 & 10.3 & 10.3 & 100.0 \\
Total & 300 & 100.0 & 100.0 & \\
\hline
\end{tabular}

The above table is indicating that for 1 to 2 years of time, most of the respondents, based on $26 \%$ are associated with banks. Besides, since 2 to 3 years, $15 \%$ of the respondents are connected with the banks. In addition to this, for 3 to 4 years there are $12 \%$, for 6 to 7 years, there are $11 \%$, for 7 to 8 years there are $10 \%$. Furthermore, $10 \%$ of respondents for more than 8 years, and 5 to 6 years, whereas, for 4 to 5 years, there are only $3 \%$ respondents.

\section{Rationale behind Endorsing a Brand}

Table 4: Rational behind Endorsing a Brand

\begin{tabular}{|c|c|c|c|c|c|}
\hline & & Frequency & Percent & Valid Percent & $\begin{array}{c}\text { Cumulative } \\
\text { Percent }\end{array}$ \\
\hline \multirow[t]{6}{*}{ Valid } & $\begin{array}{l}\text { To enhance the brand } \\
\text { image }\end{array}$ & 109 & 36.3 & 36.3 & 36.3 \\
\hline & To gain fame & 102 & 34.0 & 34.0 & 70.3 \\
\hline & Raise awareness & 61 & 20.3 & 20.3 & 90.7 \\
\hline & Emotional Attachment & 24 & 8.0 & 8.0 & 98.7 \\
\hline & Just for Money & 4 & 1.3 & 1.3 & 100.0 \\
\hline & Total & 300 & 100.0 & 100.0 & \\
\hline
\end{tabular}

On the basis of above results, it can be stated that to improve the image of a brand, $36 \%$ of respondents believe that the brand endorsement is used, while 36\% think it is used to gain fame. Moreover, it is thought by $20 \%$ that to raise awareness, it is used, where the use of it for emotional attachment is thought by $8 \%$. However, there are $1 \%$ respondents who think it is used only for money. 
Influencer Endorsement Advantages

Table 5: Influencer Endorsement Advantages

How the influencer endorsement benefits you?

\begin{tabular}{|ll|r|r|r|r|}
\hline & & & & \multicolumn{1}{c|}{$\begin{array}{c}\text { Cumulative } \\
\text { Percent }\end{array}$} \\
\hline Valid & Increase Satisfaction & 113 & 37.7 & 37.7 & 37.7 \\
& Increase Loyalty & 126 & 42.0 & 42.0 & 79.7 \\
& 61 & 20.3 & 20.3 & 100.0 \\
Increase Trust & 300 & 100.0 & 100.0 & \\
\hline
\end{tabular}

Based on the results, it can be stated that as increase satisfaction, $38 \%$ respondents, whereas as increase loyalty $42 \%$ respondents, and as increase trust, $20 \%$ respondents.

\section{Online Reviews}

Table 5: Online Reviews Seeking

Why do you seek online reviews?

\begin{tabular}{|ll|r|r|r|r|}
\hline & & & & Cumulative \\
& & Frequency & Percent & Valid Percent & \multicolumn{1}{|c|}{ Percent } \\
\hline Valid & Easily Available & 105 & 35.0 & 35.0 & 35.0 \\
& Accurate & 137 & 45.7 & 45.7 & 80.7 \\
& Provide Holisitc View & 58 & 19.3 & 19.3 & 100.0 \\
& 300 & 100.0 & 100.0 & \\
\hline
\end{tabular}

The above results indicate that accuracy of online responses is believed by $45 \%$ of the respondents. The easily availability of online reviews is believed by $35 \%$, while $19 \%$ believe that there are holistic views are provided by online reviews.

Online Reviews and Buying Bank Products

Table 6: Online Reviews and Buying Bank Products

How Does online reviews help you to buy any product from bank?

\begin{tabular}{|c|c|c|c|c|c|}
\hline & & Frequency & Percent & Valid Percent & $\begin{array}{c}\text { Cumulative } \\
\text { Percent }\end{array}$ \\
\hline \multirow[t]{5}{*}{ Valid } & $\begin{array}{l}\text { Increase knowledge } \\
\text { about product information }\end{array}$ & 61 & 20.3 & 20.3 & 20.3 \\
\hline & $\begin{array}{l}\text { Get referrals from social } \\
\text { network }\end{array}$ & 163 & 54.3 & 54.3 & 74.7 \\
\hline & $\begin{array}{l}\text { Explore the pros and } \\
\text { cons }\end{array}$ & 72 & 24.0 & 24.0 & 98.7 \\
\hline & Builds Trust & 4 & 1.3 & 1.3 & 100.0 \\
\hline & Total & 300 & 100.0 & 100.0 & \\
\hline
\end{tabular}

The above results show that $54 \%$ believe that in buying bank products, they are provided help by referral from social network. Online reviews are thought to be useful in increasing knowledge by $20 \%$, whereas as per $24 \%$, it helps to explore pros and cons, and $1 \%$ thinks that trust in financial products and banks is built by it.

Influence on Banking Habits by Most Favourite Personality

Table 7: Influence on Banking Habits by Most Favourite Personality

What type of personality most likely to influence your banking habits

\begin{tabular}{|c|c|c|c|c|c|}
\hline & & Frequency & Percent & Valid Percent & $\begin{array}{c}\text { Cumulative } \\
\text { Percent }\end{array}$ \\
\hline \multirow[t]{6}{*}{ Valid } & Sports Personality & 109 & 36.3 & 36.3 & 36.3 \\
\hline & Entertainment & 102 & 34.0 & 34.0 & 70.3 \\
\hline & National Heros & 51 & 17.0 & 17.0 & 87.3 \\
\hline & Young entrepreneurs & 30 & 10.0 & 10.0 & 97.3 \\
\hline & Other personalities & 8 & 2.7 & 2.7 & 100.0 \\
\hline & Total & 300 & 100.0 & 100.0 & \\
\hline
\end{tabular}

Based on the above table, sports personality in Pakistan is preferred by $36 \%$ respondent, entertainment personality 
is preferred by $34 \%$, national heroes are preferred by $17 \%$, while young entrepreneurs are preferred by $10 \%$ and other personalities are preferred by $3 \%$.

\subsection{Correlation Analysis}

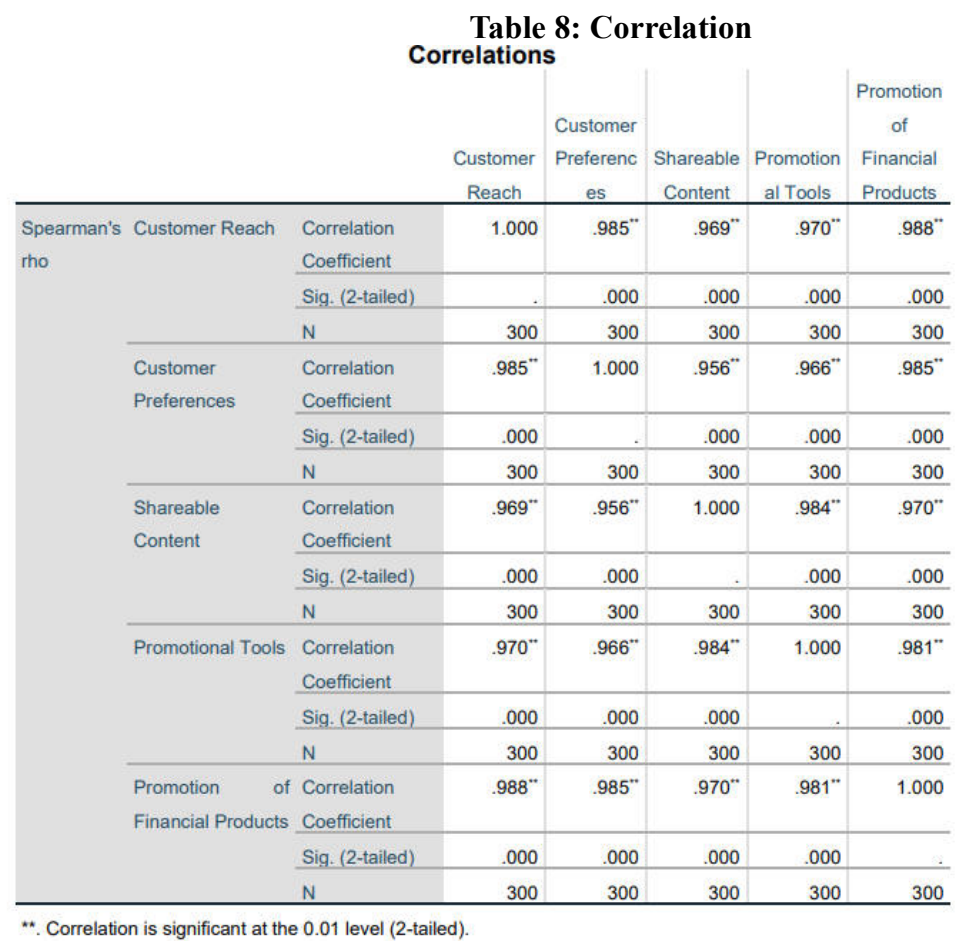

It can be stated on bases of above results of dependent and independent variables that the value of Alpha (5\%) is not exceeded by the value of significance, and the statement of null hypothesis is rejected by it. 0.988 with significant value of 0.000 is the result of the Spearman rho correlation coefficient, and therefore, it can be deduced that between customer reach and promotion of financial products, there is positive and strong relationship. Besides, the promotion of financial products would be increased or vice versa by the increment in consumer reach.

Furthermore, it is also observable that the value of Alpha (5\%) is not exceeded by the value of significance, and the statement of null hypothesis is rejected by it. 0.985 with significant value of 0.000 is the result of the Spearman rho correlation coefficient, and therefore, it can be deduced that between customer preferences and promotion of financial products, there is positive and strong relationship. Besides, the promotion of financial products would be increased or vice versa by the increment in consumer reach.

Also, the value of Alpha (5\%) is not exceeded by the value of significance, and the statement of null hypothesis is rejected by it. 0.970 with significant value of 0.000 is the result of the Spearman rho correlation coefficient, and therefore, it can be deduced that between sharable content and promotion of financial products, there is positive and strong relationship. Besides, the promotion of financial products would be increased or vice versa by the increment in consumer reach.

Based on above table, in the last relationship, the value of Alpha (5\%) is not exceeded by the value of significance, and the statement of null hypothesis is rejected by it. 0.981 with significant value of 0.000 is the result of the Spearman rho correlation coefficient, and therefore, it can be deduced that between promotional tools and promotion of financial products, there is positive and strong relationship. Besides, the promotion of financial products would be increased or vice versa by the increment in consumer reach.

\subsubsection{Chi-Square Test}

As the data were non-parametric and ordinal, therefore, this test is utilised by the researcher. The results of the test are presented below: 
Table 9: Customer Reach and Promotion of Financial Products Chi-Square

\begin{tabular}{l|r|r|r} 
& Chi-Square Tests & \multicolumn{1}{c}{$\begin{array}{c}\text { Asymptotic } \\
\text { Significance (2- } \\
\text { sided) }\end{array}$} \\
\hline Pearson Chi-Square & $24.061^{\mathrm{a}}$ & 4 & .000 \\
\hline Likelihood Ratio & 23.836 & 4 & .000 \\
\hline Linear-by-Linear Association & 16.314 & 1 & .000 \\
\hline N of Valid Cases & 300 & & \\
\hline
\end{tabular}

a. 2 cells $(5.5 \%)$ have expected count less than 5 . The minimum

expected count is 3.00 .

Table10: Customer Reach and Promotion of Financial Products Symmetric Measurement

\begin{tabular}{llr|r}
\multicolumn{2}{l}{ Symmetric Measures } & \\
& & Value & \multicolumn{1}{c}{$\begin{array}{c}\text { Approximate } \\
\text { Significance }\end{array}$} \\
\hline Nominal by Nominal & Phi & .310 & .000 \\
\cline { 2 - 4 } & Cramer's V & .219 & .000 \\
\hline N of Valid Cases & & 300 & \\
\hline
\end{tabular}

The association between the customer reach and promotion of financial products has been tested. Based on the above results, with a p value of 0.000 the Pearson's chi-square is 24.061, there is statistically significant relationship between the variables, and there is rejection of null hypothesis (Ha). Besides, the results of symmetric measures indicate that there is not strong relationship between customer reach with promotion of financial products because Cramer's V is calculated as 0.219 and is below 0.3.

Table 11: Customer Preferences and Promotion of Financial Products Chi-Square

\begin{tabular}{|c|c|c|c|}
\hline \multicolumn{4}{|c|}{ Chi-Square Tests } \\
\hline & Value & $\mathrm{df}$ & $\begin{array}{c}\text { Asymptotic } \\
\text { Significance (2- } \\
\text { sided) }\end{array}$ \\
\hline Pearson Chi-Square & $40.215^{a}$ & 4 & .000 \\
\hline Likelihood Ratio & 36.124 & 4 & .000 \\
\hline Linear-by-Linear Association & 13.145 & 1 & .000 \\
\hline $\mathrm{N}$ of Valid Cases & 300 & & \\
\hline
\end{tabular}

a. 2 cells $(16.3 \%)$ have expected count less than 5 . The minimum expected count is 2.02 . 
Table 12: Customer Preferences and Promotion of Financial Products Symmetric Measurement

\begin{tabular}{llr|r}
\multicolumn{2}{c}{ Symmetric Measures } & \multicolumn{2}{c}{$\begin{array}{c}\text { Approximate } \\
\text { Significance }\end{array}$} \\
\hline Nominal by Nominal & Value & .000 \\
\cline { 2 - 4 } & Phi & .946 & .000 \\
\hline N of Valid Cases & & .545 & \\
\hline
\end{tabular}

The results of Chi-square indicate that there is statistically significant relationship of customer preference with promotion of financial products where the null hypothesis $(\mathrm{Hb})$ is rejected as with a $\mathrm{p}$ value of 0.000 , the Pearson's chi-square is 40.215 . Besides, the results of symmetric measures indicate that there is moderate relationship between customer reach with promotion of financial products because Cramer's V is calculated as 0.545 and is above 0.3 .

Table 13: Sharable Content and Promotion of Financial Products Chi-Square

\begin{tabular}{l|r|r|r} 
& & & \multicolumn{2}{c}{$\begin{array}{c}\text { Asymptotic } \\
\text { Significance (2- } \\
\text { sided) }\end{array}$} \\
\hline Value & df & & .000 \\
\hline Pearson Chi-Square & $169.807^{\mathrm{a}}$ & 4 & .000 \\
\hline Likelihood Ratio & 151.851 & 4 & .000 \\
\hline Linear-by-Linear Association & 80.482 & 1 & \\
\hline N of Valid Cases & 300 & & \\
\hline
\end{tabular}

a. 2 cells $(11.7 \%)$ have expected count less than 5 . The minimum

expected count is 3.43 .

Table 14: Sharable Content and Promotion of Financial Products Symmetric Measurement

Symmetric Measures

\begin{tabular}{llr|r} 
& & \multicolumn{2}{c}{$\begin{array}{c}\text { Approximate } \\
\text { Significance }\end{array}$} \\
\hline Nominal by Nominal & Phi & 1.44 & .000 \\
\cline { 2 - 4 } & Cramer's V & 1.375 & .000 \\
\hline N of Valid Cases & & 300 & \\
\hline
\end{tabular}

The results of Chi-square indicate that there is statistically significant relationship of sharable content with promotion of financial products where the null hypothesis $(\mathrm{Hc})$ is rejected as with a p value of 0.000 , the Pearson's chi-square is 169.807 . Besides, the results of symmetric measures indicate that there is very strong relationship between customer reach with promotion of financial products because Cramer's V is calculated as 1.375 and is close to 1 . 
Table 15: Promotional Tools and Promotion of Financial Products Chi-Square

\begin{tabular}{l|r|r|r} 
& & & \multicolumn{2}{c}{ Chi-Square Tests } \\
& Value & df & \multicolumn{2}{c}{$\begin{array}{c}\text { Significance (2- } \\
\text { sided) }\end{array}$} \\
\hline Pearson Chi-Square & $67.631^{\mathrm{a}}$ & 4 & .000 \\
\hline Likelihood Ratio & 70.192 & 4 & .000 \\
\hline Linear-by-Linear Association & 32.420 & 1 & .000 \\
\hline N of Valid Cases & 300 & & \\
\hline
\end{tabular}

a. 3 cells $(12.5 \%)$ have expected count less than 5 . The minimum

expected count is 2.02 .

Table 16: Promotional Tools and Promotion of Financial Products Symmetric Measurement Symmetric Measures

\begin{tabular}{|c|c|c|c|}
\hline & & Value & $\begin{array}{l}\text { Approximate } \\
\text { Significance }\end{array}$ \\
\hline \multirow[t]{2}{*}{ Nominal by Nominal } & Phi & 1.228 & .000 \\
\hline & Cramer's V & .708 & .000 \\
\hline N of Valid Cases & & 300 & \\
\hline
\end{tabular}

The results of Chi-square indicate that there is statistically significant relationship of promotional tools with promotion of financial products where the null hypothesis $(\mathrm{Hd})$ is rejected as with a p value of 0.000 , the Pearson's chi-square is 67.631. Besides, the results of symmetric measures indicate that there is strong relationship between promotional tools with promotion of financial products because Cramer's V is calculated as 0.708 and is close to 1.

\section{Conclusion}

This research is objected to recognising the role of influencer marketing in promoting financial products in the banking industry of Pakistan. Initially, the identified problem which has the focus of this study is the insufficiency of previous studies related to influencer marketing which are undertaken in consideration of Pakistan.

The results of this research are significant for the Pakistani banks in order to increase their sales by integrating influencer marketing. For supporting the findings this research uses the applications of cost per engagement model for influencer marketing and competitive pricing model for deciding the pricing of the products in accordance with competitive market. It has been analysed that influencer marketing is related to the usage of individual who are capable to appeal and fascinate customers by originating long standing effect. The shareable content is deliberated as most important for influencer marketing that supports the convenient communication related to products with customers. There are various techniques for implementing influencer marketing such as the banks should use celebrity endorsement in order to affect the minds of customers about the products and services. Likewise, through the analysis of this study, the effect of influencer marketing was originated to be significant on the promotion and advertisement of financial products in the banking sector of Pakistan. In last, the banking sector of Pakistan should change their strategies towards influencer marketing because customers of financial institutions of Pakistan are also changed. Currently, the majority of customer wanted and entirely relying on the advanced and digital banking type of products and services. Based on the finding of the study following recommendations have been provided: The process of digitalisation should be adopted by banks. The reason is that it will provide benefits to the banks in term of profitably because in the recent time people more likely to prefer to use digital medium for their convenience. As it has been analysed in the research that for the purpose of influencing the public for the products, the entertainment personalities and sports personalities are being endorsed. Therefore, this should be considered by banks for the purpose of influencer marketing because the perception and attitude of people towards brand is positively affected by celebrity endorsement. The banks in Pakistan should effective measures the customers are offered genuine information. However, this can be done by the banks if the marketing functions should properly be monitored and controlled. 


\section{Limitations and Future Research}

This study specifically focused on the banking sector of Pakistan, which means the findings of the study is limited to the banking sector of Pakistan only, however, future studies can be conducted on different banks in different countries as each country have different standards for banking. The data in this study was obtained through survey questionnaire, and hence, the sample was 300 but future studies can take larger samples to study the phenomena in detail. There had been limited knowledge possessed by respondents despite the awareness of the topic as they were all consumers, and not bank managers or experts, so future studies can be conducted among bank managers or field experts.

\section{References}

Abdallah, M., (2015). Indirect Marketing through Influencers on Social Media: Comparing Facebook paid advertisement services to advertisement by influencers on social media.

Aftab, H., (2012). A Study of Job Satisfaction and IT's Impact on the Performance in the Banking Industry of Pakistan. International Journal of Business and Social Science, 3(19).

Angelini, A., Ferretti, P., Ferrante, G. \& Graziani, P., (2017). Social media development paths in banks. Journal of Promotion Management, 23(3), pp.345-358.

BenYoussef, N., \& Breton, G. (2016). Restatement announcements: sincerity analysis through information manipulation theory. Available at SSRN 1985680.

Berne-Manero, C., \& Marzo-Navarro, M. (2020). Exploring How Influencer and Relationship Marketing Serve Corporate Sustainability. Sustainability, 12(11), 4392.

Bhattacharya, J. (2017). Top 25 Digital Marketing Influencers to Follow in 2017 - Relevance. [online] Relevance. Available at: https://www.relevance.com/top-25-digitalmarketing-influencers-to-follow-in-2017

Biaudet, S., (2017). Influencer Marketing as a Marketing Tool: The process of creating an Influencer Marketing Campaign on Instagram.

Bodimeade, H., Anderson, E., La Macchia, S., Smith, J.R., Terry, D.J. \& Louis, W.R., (2014). Testing the direct, indirect, and interactive roles of referent group injunctive and descriptive norms for sun protection in relation to the theory of planned behavior. Journal of Applied Social Psychology, 44(11), pp.739-750

Bokhari, J. (2017). Banking industry is facing organic stress. [online] DAWN.COM. Available at: https://www.dawn.com/news/1347302 [Accessed 6 June 2020].

Bokunewicz, J.F. \& Shulman, J., (2017). Influencer identification in Twitter networks of destination marketing organisations. Journal of Hospitality and Tourism Technology, 8(2), pp.205-219

Bokunewicz, J.F. and Shulman, J., (2017). Influencer identification in Twitter networks of destination marketing organisations. Journal of Hospitality and Tourism Technology, 8(2), pp.205-219.

Brown, D., \& Hayes, N. (2008). Influencer marketing. Routledge.

Cha, M., Haddadi, H., Benevenuto, F., \& Gummadi, K. P. (2010, May). Measuring user influence in twitter: The million follower fallacy. In fourth international AAAI conference on weblogs and social media.

Choudhury, K., (2014). The influence of customer-perceived service quality on customers' behavioural intentions: a study of public and private sector banks, class and mass banking and consumer policy implications. International Review on Public and Nonprofit Marketing, 11(1), pp.47-73.

Dongmei, Z., \& Xinxin, Y. (2018). Research on Pricing Strategy of Limited Rational Consumer Brand Conversion Behavior. Price: Theory \& Practice, (9), 33.

El Khoury, J. and Farah, D., 2018. OPINION LEADERS IN 2019-ADVERTISING AND PUBLIC RELATIONS. International Journal of Arts \& Sciences, 11(1), pp.451-460.

Etikan, I., Alkassim, R., \& Abubakar, S. (2016). Comparision of snowball sampling and sequential sampling technique. Biometrics and Biostatistics International Journal, 3(1), 55.

Florian, U., (2015). Influencer Management in a Social Web Environment Identification and Supervision of Opinion Leaders for Influencing Customer Purchase Decisions.

Gogtay, N. J., \& Thatte, U. M. (2017). Principles of correlation analysis. Journal of the Association of Physicians of India, 65(3), 78-81.

Gretzel, U. (2018). Influencer marketing in travel and tourism. Advances in social media for travel, tourism and hospitality: New perspectives, practice and cases, 147-156.

Haleem, F. (2015). Planning Change in an Organization; MCB Bank Limited, Pakistan. Journal of Central Banking Theory and Practice, 4(2), 75-107.

Janefer, C. \& Siddiq, A., (2017). A Study on Customer Awareness towards Banking Service with reference to Deposit and Loan in Mangaluru City. International Journal on Recent and Innovation Trends in Computing and Communication, 5(7), pp.520-522

Jin, S. V., Muqaddam, A., \& Ryu, E. (2019). Instafamous and social media influencer marketing. Marketing Intelligence \& Planning 
Johnston, M. P. (2017). Secondary data analysis: A method of which the time has come. Qualitative and quantitative methods in libraries, 3(3), 619-626.

Kim, D. Y., \& Kim, H. Y. (2019, December). An Influencer Like Me: Does Influencer Social Status Matter?. In International Textile and Apparel Association Annual Conference Proceedings (Vol. 76, No. 1). Iowa State University Digital Press.

Kouser, R. and Saba, I., (2011). Effects of Business combination on financial performance: Evidence from Pakistan's Banking Sector. Australian Journal of Business and Management Research, 1(8), p.54

Kumar, V., \& Pradhan, P. (2018). Trust management issues in social-media marketing. In Social Media Marketing: Breakthroughs in Research and Practice (pp. 714-732). IGI Global.

Leavy, P. (2017). Research design: Quantitative, qualitative, mixed methods, arts-based, and community-based participatory research approaches. Guilford Publications.

Lou, C., \& Yuan, S. (2019). Influencer marketing: how message value and credibility affect consumer trust of branded content on social media. Journal of Interactive Advertising, 19(1), 58-73.

Mir, I., (2015). Effects of Beliefs and Concerns on User Attitudes toward Online Social Network Advertising and Their Ad Clicking Behavior. The Journal of Internet Banking and Commerce, 2015.

Morgan, G. \& Engwall, L., (2018). Regulation and Organisations: International Perspectives. Routledge.

Rizwan, M., Javed, M.A., Khan, M.T., Aslam, M.T., Anwar, K., Noor, S. and Kanwal, W., (2013). The Impact of Promotional Tools on Consumer Buying Behavior: A Study from Pakistan. Asian Journal of Empirical Research, 3(2), pp.114-130

Ruiz-Gomez, A. (2019). Digital fame and fortune in the age of social media: A classification of social media influencers. adResearch ESIC, 19(19), 8-29. doi: 10.7263/adresic-019-01

Shannahan, R.J., Shannahan, K.L., Bush, A.J. \& Moncrief, W.C., (2016). Taking the Good with the BadCustomer Type as a Segmentation Criterion and Differential Influencer of Sales Performance. Journal of Marketing Theory and Practice, 24(3), pp.283-305

Smith, K., Georgieva, E., Haller, J., Smith, P., Lal, R., \& Wu, Y. (2017). Reliability Testing of AlGaN/GaN Power Switch Devices at Low and High Temperature. In 2017 ROCS Workshop, May.

Sundaram, A., (2017). Leveraging Social Media for Development in Organisations. Asian Social Science, 13(4), p.201.

Tsitsi Chikandiwa, S., Contogiannis, E. and Jembere, E., (2013). The adoption of social media marketing in South African banks. European Business Review, 25(4), pp.365-381

van Staden, M., \& van Niekerk, L. (2018). Uncovering the value of influencer marketing through social network analysis and brand positioning insights. SAMRA,[Online] Available from: http://www. samra. co. za/wpcontent/uploads/Van-Staden-Van-Niekerk_Uncovering-the-value-of-influencer-marketing. pdf

Vivek, S.D., Beatty, S.E. and Morgan, R.M., (2012). Customer engagement: Exploring customer relationships beyond purchase. Journal of Marketing Theory and Practice, 20(2), pp.122-146.

Weiss, R., (2013). Influencer marketing. How word-of-mouth marketing can strengthen your organisation's brand. Marketing health services, 34(1), pp.16-17. 